al-Ihkam: Jurnal Hukum dan Pranata Sosial, 15 (1), 2020: 50-66

ISSN: 1907-591X, E-ISSN: 2442-3084

DOI: http://doi.org/10.19105/al-ihkam.v15i1.2729

\title{
The Meaning of Happiness and Religiosity for Pre-Prosperous Family; Study in Manado, Bandar Lampung, and Yogyakarta
}

\author{
Ahmad Rajafi \\ Institut Agama Islam Negeri Manado, \\ Jl. Dr. S.H. Sarun dajang Kawasan Ringroad I, Kota Manado \\ Email:ahmad.rajafi@gmail.com \\ Naili Adilah Hamhij \\ Universitas Islam Negeri Raden Intan Lampung, Jl. Letnan Kolonel H Jl. Endro \\ Suratmin, Sukarame, Kec. Sukarame, Kota Bandar Lampung \\ Suyatno Ladiqi \\ University Sultan Zainal AbidinTerengganu, Kampung Gong Badak, 21300, \\ Terengganu, Malaysia
}

Article history: Received: 16 November 2019, Accepted: 10 Maret 2020, Published: 27 Juni 2020

\begin{abstract}
:
Based on research conducted in 2017, this article wants to explain correlation between happiness and religiosity for pre-prosperous families. The research took place in Manado, North Sulawesi Province, Bandar Lampung, Lampung Province, and Yogyakarta. This study wanted to prove a popular assumption that religious pre-prosperous people are typically not happy. It found a positive and significant relationship between happiness and religiosity in pre-prosperous families in Yogyakarta, but not in Manado and Bandar Lampung. The highest level of happiness is in Yogyakarta and the highest level of religiosity is in Manado. This difference occurs because the concept of happiness for religious pre-prosperous families in Manado, Yogyakarta and Bandar Lampung has different point of views and uniqueness.
\end{abstract}

Author correspondence email: ahmad.rajafi@gmail.com Available online at: http:// ejournal.iainmadura.ac.id/index.php/alihkam/ Copyright (c) 2020 by al-ihkam. All Right Reserved 


\section{Keywords:}

Happiness; Religiousity; Family; Pre-Prosperous

\section{Abstrak:}

Artikel hasil dari penelitian di tahun 2017 ini ingin menjelaskan tentang korelasi bahagia dengan religiusitas bagi keluarga miskin. Locus penelitian berada di Kota Manado Propinsi Sulawesi Utara, Kota Bandar Lampung Propinsi Lampung, dan Kota Yogyakarta di Propinsi Daerah Istimewa Yogyakarta. Penelitian ini menjadi penting karena adanya asumsi di masyarakat bahwa orang yang miskin mesikipun religius dipasti tidak akan bahagia, hal ini terpatahkan dengan hasil penelitian ini, dimana hasilnya menunjukkan bahwa terdapat hubungan yang positif dan signifikan antara kebahagiaan religiusitas pada keluarga miskin di Kota Manado, Bandar Lampung dan Yogyakarta. Religiusitas berkorelasi positif dengan ke bahagiaan di Kota Yogyakarta, Bandar Lampung dan Manado. Tingkat kebahagiaan tertinggi ada di Kota Yogyakarta dan tingkat religiusitas tertinggi ada di kota Manado.

\section{Kata Kunci:}

Bahagia; Religious; Keluarga; Miskin

\section{Introduction}

Manado is a religious city with various nicknames such as the City of Thousand Churches, the City of Prayer, and so forth. Therefore, it is easy to find a variety of well-organized religious activities such as what is popular as mapalus. It is a mutual cooperation in which people raise food from each household then distribute it to those who need it. Serving as a minority, Moslems in Manado also engage in this activity.

Likewise, the city of Bandar Lampung also seems religious as clear from some religious symbols in public places, such as a welcoming gate that reads two shahada (Islamic confession), the central government's gateway that reads the names of God, and even the government's monthly agenda called tabligh akbar with some national preachers. The last agenda aims to provide religious knowledge intake to the community. 
Meanwhile, besides known as the city of students, Yogyakarta also shows religious values through Javanese customs. The values are found in most of kingdom's routine activities such as labuan ceremonies, sekaten, nguras enceh, bekakak, grebek muludan and so on. All aim to strengthen community's religious values, and a strong religious motivation is required in order to restore the Islamic community. ${ }^{1}$

However, the fact that those three cities are quite intense in showing their religious identity does not mean the prosperousity of their people as such. Data at BPS even shows that underprivileged people in Manado at 2014 amounted to 286,498 people. It then rose to 313,236 people in 2015 and rose again at 2016 to 334,732 people. $^{2}$ Bandar Lampung is also the same. Every year, it experiences an increase in the number of poor people. It has 359,948 poor people at 2011, 392,642 people at 2012, and 429,146 people at 2013. ${ }^{3}$ Uniquely, poverty rate at Yogyakarta goes up and down. It had 32,060 people at $2016,32,200$ people at 2017 , and 29,750 people at $2018 .^{4}$

The data shows a gap between religious values and prosperousity. There are at least three basic assumptions on why this happens; First, government's programs and policies in eradicating poverty needs to be based on various studies from several

1 Idi Warsah et al., "Muslim Minority In Yogyakarta: Between Social Relationship and Religious Motivation," Qudus International Journal of Islamic Studies 7, no. 2 (2019): 374, https://doi.org/10.21043/qijis.v7i2.6873; Ahmed M Abdel-Khalek, "Religiosity, Health and Happiness: Significant Relations in Adolescents from Qatar," International Journal of Social Psychiatry 60, no. 7 (2014): 657, https://doi.org/10.1177/0020764013511792.

2 BPS North Sulawesi, “Garis Kemiskinan Di Kota Manado, 2004-2015," Blog, Badan Pusat Statistik Kota Manado (blog), August 18, 2017, https://manadokota.bps.go.id/statictable/2017/08/18/202/garis

kemiskinan-di-kota-manado-2004-2016.

3 BPS Bandar Lampung, "Garis Kemiskinan 2010-2014," Blog, Garis Kemiskinan Kota Bandar Lampung 2010-2013 (blog), December 6, 2019, https:/ / bandarlampungkota.bps.go.id/statictable/2015/12/08/16/garis\%20kemiskinan\%20kota-bandar-la\%20BPS.

4 BPS Yogyakarta, “Tabel Kemiskinan Kota Yogyakarta," 6 Desember 2019, https://jogjakota.bps.go.id/dynamictable/2019/01/08/32/tabelkemiskinan kotayogyakarta.html. 
perspectives and disciplines, one of which is the study of familypsychology;

Second is common assumption that generally, underprivileged families enjoy their situation. They are considered to feel accustomed to their living conditions while feeling "happy" on it. Therefore, no matter what government's programs and policies are, it will not work well to change the condition. In the psychological term, this is called by learned helplessness.

In short, learned helplessness leads people to be over selfconfidence and makes them think that any effort they do will not result anything good. Scientific studies show that in dealing with difficult situations and hard challenges, some people turn out to "learn" to be helpless. This "learning" process makes them give worse performance than what they could actually do. ${ }^{5}$

In fact, according to Quraish Shihab, ${ }^{6}$ when someone gets lazy, he actually hurts himself because Allah has certainly guaranteed sustenance for all his creatures, including "dabbah", which literally means "to move" (Q.S Hud [11]: 6). However, this guarantee only applies for those who are always on the move to gain sustenance from Allah. It is not for people who do nothing and hope for other people's help. ${ }^{7}$ In another verse, Allah remindes us to always go forward because He will not change any situation of certain people until they make changes and improvements themselves. (Q.S al-Ra'd [13]: 11).

Third is another public perspective that in Islam, pre-prosperity condition is a divine test or trial as well as destiny. Some people even consider poverty as a test of faith so that they have to be positive thinking to God Almighty. ${ }^{8}$ This mindset encourages gratitude and happiness with what they have although they are lack of many things. They further think that happiness is felt by themselves even in a hard

5 Michael T. Bixter, "Happiness, Political Orientation, and Religiosity," Personality and Individual Differences 72 (2015): 8, https://doi.org/10.1016/j.paid.2014.08.010.

6 Muhammad Quraish Shihab, Wawasan Alqur'an: Tafsir Maudhu'i Atas Berbagai Persoalan Umat, 14th ed. (Bandung: Mizan, 1996), 443.

7 Shihab, Wawasan Alqur'an..., 443.

8 Syarif Imam Hidayat, "Kemiskinan Dalam Perspektif Masyarakat Desa Tertinggal Yang Religius" (Disertasi, Malang, Universitas Brawijaya, 2011), 2. 
economic condition in which other people will think it as very vulnerable ones.

In this talk, religiosity is one of influencing factors on someone's happiness. The above mentioned mindset makes them accustomed to keep doing nothing, reluctant, and helpless to try anything. This phenomenon indirectly implies that religion teaches poverty. In fact, some people assume that poverty has something to do with certain religious understanding well spreaded in Indonesia, namely sufism. Whereas, the Qur'an has clearly stated on synergy between the wordly will and the will of hereafter (QS. Al-Qashash [28]: 77).

Additionally, Abu Hurairah has also narrated a hadith from the Messenger of Allah about a strong believer who is better (in Allah's eyes) compared to the weak ones. The strong believer means that he/she needs to work hard and be active so that the power of faith can well correlate to physical and financial strength. ${ }^{9}$

The explanation above confirms that this research will be among the first steps in formulating happiness concept based on different cultural perspective in some Indonesian regions, especially the City of Manado, the City of Bandar Lampung and the City of Yogyakarta. It focuses, however on the concept of happiness for pre-prosperous Muslims families.

Sampling of Muslim families becomes important because presurveys on a few months in 2016 (January to September 2016) show how Moslem underprivileged families in the cities of Manado, Bandar Lampung, and Yogyakarta are quite largely spread. In fact, those three cities are well known in their regional development program with the concept of religiosity.

\section{Research Method}

This research uses a mixed method which tries to synergize quantitative and qualitative methods. It aims to obtain research data that is complete and valid as well as reliable and objective. The mix also enables researchers to avoid each quantitative and qualitative

9 Mohammad Irhan, "Etos Kerja Dalam Perspektif Islam," Jurnal Substansia 14, no. 1 (April 2012): 19. 
method's disadvantages. 10 The technique used in this mixed method is the concurrent model so that the researcher can assemble the data found from one research method to another by scaling first to produce quantitative data then proceeding with the interview in order to produce qualitative data. The object research of this study and the cities are chosen based on several variable criteria.

\section{Data Presentation}

Data obtained from a sample of 234 people from 3 cities in Indonesia, namely Manado, Yogyakarta and Bandar Lampung shows that the overall happiness scale has 11 as the lowest value while the highest was 36. The standard deviation is 5.091 and the mean is 27.82 . Meanwhile, the religiosity lowest scale was 72 and the highest is 108

with 7154 as the standard deviation and 95.71 as the mean. Following is the distribution table:

\section{Table 1}

Description of Statistics

\begin{tabular}{||l||l||l||}
\hline \multicolumn{1}{|c||}{ Happiness } & \multicolumn{1}{c|}{ Religiosity } \\
\hline N Valid $\quad$ Missing & 234 & 234 \\
Mean & 0 & 0 \\
Median & 27.82 & 95.71 \\
Std. Deviation & 29.00 & 95.00 \\
Minimum & 5.091 & 7.154 \\
Maximum & 11 & 72 \\
\hline \hline
\end{tabular}

As for the grouping of happiness values was made in three models namely high, medium, and low. Calculation of value grouping is as follows:

10 Sugiyono, Metode Penelitian Kombinasi (Mixed Methods) (Bandung: CV. Alfabeta, 2011), 48. 
Table 2

Happiness Score Category

\begin{tabular}{|c||c|c|c||}
\hline Category & Score & Frequency & Percentage \\
\hline \hline High & $25-35$ & 196 & $84 \%$ \\
\hline \hline Medium & $13-24$ & 35 & $15 \%$ \\
\hline \hline Low & $1-12$ & 3 & $1 \%$ \\
\hline \hline \multicolumn{2}{|c|}{ Total } & $\mathbf{2 3 4}$ & $\mathbf{1 0 0} \%$ \\
\hline
\end{tabular}

The table above shows that the number of respondents with high level of happiness is 196 people $(84 \%)$, 35 people $(15 \%)$ at moderate level and 3 people $(1 \%)$ at low level. This explains that respondents with high level of happiness get the highest score. Whereas the aspect of religiosity, which is categorized as high, medium, and low categories produces answers as follows:

Table 3

Religiosity Score Category

\begin{tabular}{|c||c|c|c|}
\hline Category & Score & Frequency & Percentage \\
\hline \hline High & $73-108$ & 233 & $99,6 \%$ \\
\hline \hline Medium & $37-72$ & 1 & $0,4 \%$ \\
\hline \hline Low & $1-36$ & 0 & $0 \%$ \\
\hline \hline \multicolumn{2}{|c|}{ Total } & $\mathbf{2 3 4}$ & $\mathbf{1 0 0} \%$ \\
\hline
\end{tabular}

The table above explains that respondents with high level of religiosity are 233 people $(99.6 \%)$, moderate religiosity with 1 person $(0.4 \%)$ and there found no one at all $(0 \%)$ with low level of religiosity. This also emphasizes that the majority of respondents are at high level of religiosity. 
1. Happiness Scale Measurement Result

Diagram 1 Level of Happiness

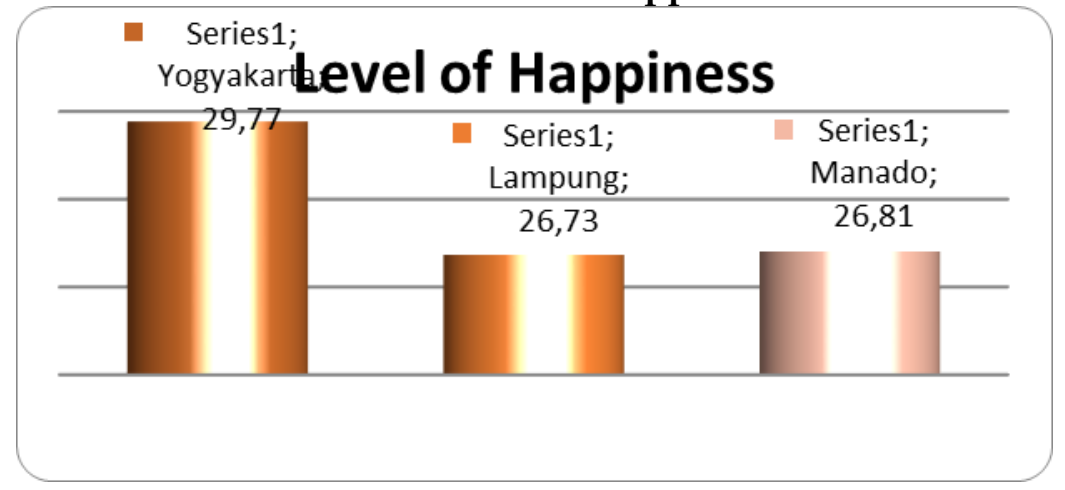

The table above shows that the highest level of happiness is in the city of Yogyakarta with 29.77 as the mean, while the lowest is in the city of Lampung with mean of 26.73 .

2. Religious Scale Measurement Result

Diagram 2

Level of Religiosity

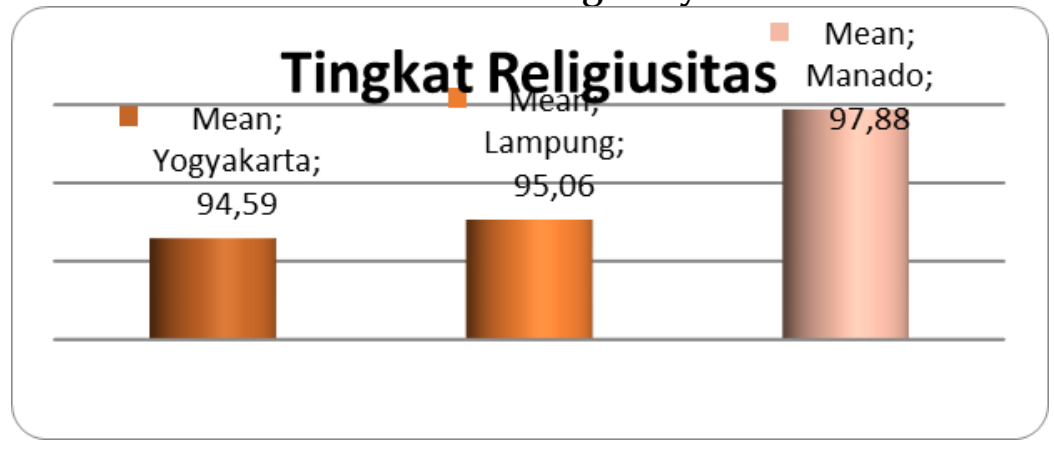

The table shows that the highest level of religiosity is in Manado with a mean of 97.88 while the lowest is in Yogyakarta with a mean of 94.59 . 
3. Correlation Test Between Happiness and Religiosity of PreProsperous Families

Hypothesis test statistical analysis in this study uses the Pearson Product Moment correlation formula while the calculation uses the SPSS program version 13.0. The result is as follows:

Table 4

Hypothesis Testing

\begin{tabular}{|c|c|c|c|c|c|}
\hline City & $\mathbf{r}$ & $\begin{array}{c}\mathbf{R} \\
\text { Square }\end{array}$ & $\mathbf{F}$ & Sig. & Information \\
\hline Yogyakarta & 0.497 & 0.247 & 26.519 & $\begin{array}{l}0.000< \\
0.01\end{array}$ & Significant \\
\hline Lampung & 0.159 & 0.025 & 2.539 & $\begin{array}{l}0.114> \\
0.05\end{array}$ & $\begin{array}{l}\text { Not } \\
\text { Significant }\end{array}$ \\
\hline Manado & 0.208 & 0.043 & 2.209 & $\begin{array}{l}0.144> \\
0.05 \\
\end{array}$ & $\begin{array}{l}\text { Not } \\
\text { Significant }\end{array}$ \\
\hline
\end{tabular}

- Religiosity is positively correlated with happiness in Yogyakarta, Lampung and Manado.

- Religion can significantly predict happiness in Yogyakarta with $\mathrm{F}=26,519$ and $\mathrm{P}<0.01$.

- Religiosity can predict happiness by $24.7 \%$.

- Religiosity cannot predict happiness in Lampung and Manado.

\section{Correlation of Happiness with Religiosity}

A religious person has firm belief which leads and guides everything he/she does to be God Almighty-oriented. In Islam, this concept is known as tawakal, which means the surrender of all affairs to Allah. Tawakkal people will conduct any worldly activities in religios manner by beginning and ending their work with prayer while wishing the harmony between their will and God's will. This will eventually create bighearted mind to accept any divine destiny that God has given.

Furthermore, this attitude will create mental strength in coping with life and its challenges. For religious groups, this kind of religious 
values can even be savior in deling with various problems and crisises. Religious belief can also shows high spiritual values which leads to positive thinking mindset to avoid them from blaming any fate they have.

This reason is in line with the research result which shows that people with low economic levels (pre-prosperous) are still able to enjoy their lives and feel happy for what they have. The main basic for their happiness comes from their attitude and religiousity. Religiosity is a solution for underprivileged people to continue surviving and living their lives while surrendering to Allah Almighty.

Self-surrender to the Almighty and belief on the existence of an external element outside human being which determines life destiny greatly helps underprivileged people to manage their negative emotions or prejudice. Instead, this will lead them for continual gratitude under any conditions. Therefore, they keep getting closer to Allah as being aware that religiosity is the basic capital to get wordly happiness.

\section{Happiness Concept of Religious Pre-Prosperous Families in Manado}

Based on data from measurement scale in the previous discussion, it is known on correlation between happiness and religiosity in Manado people at a significance level of 0.05 . This explains that the correlation is at an insignificant level, although the religiosity scale level in Manado shows the highest number. In other word, when a person experiences an increase in his/her religiosity, it is not necessarily an increase in happiness right away. Therefore, religiosity cannot predict happiness in among Manado people.

Furthermore, on the previous happiness scale, it was also found respondents who felt happy even though their economic standard was not good with a percentage of $26.81 \%$. With such assessment, a happy person actually will get used to manage his/her personality in a positive framework and therefore be able to create happiness for themselves and others while negating any unhappiness.

This study makes it clear that no significant relationship between happiness value and religiosity level. This means that happiness is not always influenced by religiosity even though religious factors are one indicator in creating happiness for each 
individual. In essence, happiness will exist along with a sense of security and comfort within oneself even in the pre-prosperous condition. Being comfortable in the midst of poverty, in other word, can even create happiness.

In the context of Manado with its plural people, local wisdom and religious values do exist and live. However at implementation level, Manado people nowadays are very difficult to synergize the values of wisdom and religion. The concept of sitou timou tou which means "we live to support others" is actually a very strong social norm born from ancestors of the toar lumi muut land. However, at the level of implementation today, they prefer another concept which is pragmatic and materialistic and reads; "it is ok for getting lose in rice as long as winning in action".

For some of Manado people, physical appearance is the most important thing. It is even considered more important than food at home. This is what drives many underprivileged Manado families to feel comfortable and happy in the midst of their poverty. In other words, culturally, underprivileged Manado people are accustomed to live with poverty and this makes them not want to try hard to improve their standard of living. In addition to it, pseudo- hedonist or prestigious lifestyle of most underprivileged Manado families leads them to have less productive habits (being passive or relying on fate) and wasteful in spending a small amount of income. As a result, they do not feel poor even though others see them as the poor.

Therefore, the phenomenon of poverty in Manado is in line with what is called by Nasikun as "cultural poverty".11 It is a type of poverty born from cultural behavior of one's life using the mindset which accepts everything right away without any slightest enthusiasm to move forward for improving quality of life and economic factors. It instead leads to the attitude of lazy, wasteful, and always expecting help from others.

${ }^{11 N a s i k u n, ~ I s u ~ D a n ~ K e b i j a k a n ~ P e n a n g g u l a n g a n ~ K e m i s k i n a n, ~ D i k t a t ~ M a t a ~ K u l i a h ~}$ (Yogyakarta: Program Magister Administrasi Publik Universitas Gadjah Mada, 2001), 12. 


\section{Happiness Concept of Religious Pre-Prosperous Families in Bandar Lampung}

The data on happiness scale in Yogyakarta, Bandar Lampung and Manado shows that the level of happiness of religious preprosperous families in Bandar Lampung is the lowest with a mean of 26.73. The highest level belongs to religious pre-prosperous families in Yogyakarta with a mean of 29.77 which then followed by Manado with a mean of 26.81 .

While for the scale of religiosity the level of underprivileged families in Bandar Lampung City is in the second position with a mean of 97.88. The highest level of religiosity is in Manado with a mean of 97.88, while the lowest is in Yogyakarta with a mean of 94.59.

The research data above illustrates insignificant relationship between the level of happiness and the level of religiosity in Bandar Lampung amounting to 0.159 and the significance $(p)=0.000 ;(p$ $<0.05)$. This shows that religiosity is not positively correlated with happiness in Bandar Lampung. In other words, the level of religiosity of most underprivileged families in Bandar Lampung cannot predict their level of happiness. This means that if there is an increase in a person's religiosity, it will not necessarily mean an increase in his/her happiness as well.

There are at least four factors that cause high poverty rates in Bandar Lampung as follow:

1. The low quality of human resources. Most of pre-prosperous people from job clusters as farm laborers, scavengers, construction workers, and small traders have elementary school education backgrounds and have no other skills. In addition, they also do not have any production resources, both land ownership and production tool, as well as network access and capital. In fact, they really want to work as a more prospective worker, let alone be civil servants. However, they seem not elligible for those more promising jobs.

2. Availability of job vacancy. They admit that they really want a more prospective job. However, no one accepts employees with unclear skills and low educational background.

3. Equality factor. Both interviews and observations show that most of them do not have their own production land as well as elucidation or training experience. 
4. Structural factors. Government's programs to improve underprivileged people's welfare only foster an attitude of dependency.

The description above shows that the typology of poverty in Bandar Lampung is categorized as a type of absolute poverty as well as structural ones. It turns out that the majority of pre-prosperous families in Bandar Lampung know that they are classified as underprivileged due to economic inability and lack of economic resources ownership. In addition, the low quality of human resources as a result of low education and lack of skills becomes another main reason which leads them to keep being comfortable with poverty they deal with.

This is further exacerbated by poverty alleviation government programs which have not been effective particularly for long term period. This is because Bandar Lampung government is still using an economic growth strategy with a top down approach. Thus, physical development programs become priority instead of more sustainable one for people's economic growth.

\section{Happiness Concept of Religious Pre-Prosperous Families in Yogyakarta}

According to Compton, every individual has different methods in defining and making happiness based on their respective culture and affordability. ${ }^{12}$ Javanese society, including Yogyakarta, for example, has high cultural values and is rich in life philosophy. One of living cultural contexts in Javanese society is the togetherness of a family. Therefore, it is easy and reasonable to find a single house with a lot of heads of families. This is based on an assumption that living together will eradicate any family difficulties and make it easy for all family members to feel happy.

Meanwhile, Herusatoto ${ }^{13}$ mentioned that sincerity (nrimo in Javaness concept) has become the main capital for Javaness people and been entrenched in organizing their lives to enlive happiness of

12 W.C. Compton, Introduction to Positive Psikologi (USA: Malloy Incorporated, 2005), 33.

${ }^{13}$ B. Herusatoto, Simbolisme Jawa (Yogyakarta: Ombak Yogyakarta, 2008), 82. 
their own. This leads them to an attitude to always accept whatever God gives them in positive manner. They will feel satisfied with any divine fate that God has set for them. Whatever occupation they have, in this context, they will be happy for that without putting any negative thoughts.

Ikhlas or nrimo will further automatically omit all forms of enviness on other people's succes. Their living mindset mentions that everything is predestined by God and the promised fortune will never run away from its owner or those who are fated for. This particularly applies for income and livelihood. However, this attitude sometimes lead to negative impact such as making someone too relaxed in life and less willing to work harder.

Such way of thinking is sometimes contradictory with how the external parties see their situation. For them, pre-prosperous life is something negative and is considered to make no happiness at all. However for those who experience it themselves, their life is a happy one due to a mindset that physical welfare or property is only entrusted from God so that they can't bring it to after death life

This is what most respondents of this study told on how they try to enjoy life without feeling have to or forcing themselves to get something more. They keep doing this even though they live in improper place with a slum atmosphere, narrow house, even altogether with some family heads in a single crowded house.

This life choice is easy to find among people in Yogyakarta. Respondents from some of the Palace Servants (Abdi Dhalem) even told how they feel very grateful and happy for what they do and get in daily life. They called it as priceless and immeasurable value even though they got a "wage" that other people think it was very unheard of worthy. The main principle they believe and rely on is devotion so that when the King gives them a land to occupy as a gift, they feel as a servant who gained much more trust from the King.

This is clear from results of data analysis using product moment analysis techniques from Pearson which shows correlation coefficient $(\mathrm{rxy})$ of 0.497 and significance $(\mathrm{p})=0.000 ;(\mathrm{p}<0.01)$. This means a significant positive relationship between religiosity and happiness among underprivileged people who live in Yogyakarta. It accentuates that the higher religiosity of a person is, the higher their happiness will be. 
It is obvious that there found an effective connection between the variables of happiness with religiosity by $24.7 \%$. While theological beliefs significantly have a positive relationship with subjective wellbeing and contribute a slightly more number, namely $24.2 \%$ to life satisfaction which then followed by happiness as a short-term positive effect.

Furthermore, interviews with 100 heads of underprivileged Islamic families spreading across several sub-districts in Yogyakarta found that what makes happiness for them are as follow:

1. Living together with the Family

There is a Javanese proverb saying "mangan ora mangan sing penting ngumpul" (having meal or not is not important as long as we are together) which reflects how Javanese community always wants to live together with their family. They will feel much more comfortable living like that in a place or environment in which they were grown up.

2. Health

Another common adage among Javanese community is sing penting waras or the most important thing is being healthy. A healthy body enables people to get what they want. They believe that as long as God has provided health, it means happiness right away because without health, a person would not be able to work and get income and when this happens, there will be nothing to eat and the family will not be happy. Therefore, they always pray for health. Moreover in Javanese culture, all earthly creatures such as trees, rocks, oceans, and so forth are considered to provide many benefits that require them to be grateful through celebration of gratitude.

The various description above show how underprivileged families in Yogyakarta are also able to get the value of happiness in their lives. Their achievement of happiness is much influenced by the values of religiosity. Religiosity becomes a positive tool to heighten their life expectancy through values of self-reliance or selfsurrender to what God has fated for them.

Those with high degree of self-surrender to God Almighty will literally trust on the existence of external help from unpredicted way and agent. This attitude will manage their life very well while removing any apathetic tendency and making the poverty affect 
nothing on their life. They will be grateful for that and keep doing it as time goes by and consequently, this makes them look happy all the time.

The phenomenon of poverty in Yogyakarta uncovers the attitude of self-surrender among most of its pre-prosperous families. Poverty indicator is mainly clear from very low work income due to less productive works such as as serving as courtiers, laborers, builders, and scavengers. This is made worse by unfair distribution of resource which leads to various forms of discrimination and helplessness situation of underprivileged families in various ways. This is futher in line with Nasikun's hypothesis which emphasizes the existence of structural poverty in which when a father is poor, all of his descendants will be typically poor as well.

\section{Conclusion}

There found positive and significant relationship between happiness and religiosity in underprivileged families in Yogyakarta, but not for Manado and Bandar Lampung. The highest level of happiness is in Yogyakarta while the highest religiosity level is in Manado. The concept of happiness of religiousity among preprosperous families in Manado, Yogyakarta and Bandar Lampung is different each other with unique way and outlook. It is found that even though in pre-prosperous condition, religious families are able to find happiness with their own concept of happiness. Each subject has different views, for example about being together with family members and doing devout worship. Almost all subjects define happiness with being together with family and devout worship.

\section{Bibliography}

Abdel-Khalek, Ahmed M. "Religiosity, Health and Happiness: Significant Relations in Adolescents from Qatar." International Journal $\begin{array}{lllll}\text { of Social Psychiatry 60, no. } 7 & \text { (2014). }\end{array}$ https://doi.org/10.1177/0020764013511792.

Bixter, Michael T. "Happiness, Political Orientation, and Religiosity." Personality and Individual Differences 72 (2015). https://doi.org/10.1016/j.paid.2014.08.010.

BPS Bandar Lampung. "Garis Kemiskinan 2010-2014." Blog. Garis Kemiskinan Kota Bandar Lampung 2010-2013 (blog), December 6, 2019. 
https:/ / bandarlampungkota.bps.go.id/statictable/2015/12/08/16/g aris-\%20kemiskinan \%20kota-bandar-la\% 20BPS.

BPS North Sulawesi. "Garis Kemiskinan Di Kota Manado, 2004-2015.” Blog. Badan Pusat Statistik Kota Manado (blog), August 18, 2017. https://manadokota.bps.go.id/statictable/2017/08/18/202/garis kemiskinan-di-kota-manado-2004-2016. BPS Yogyakarta. “Tabel Kemiskinan Kota Yogyakarta," December 6, 2019.

https://jogjakota.bps.go.id/dynamictable/2019/01/08/32/tabelkemiskinan-kota-yogyakarta.html.

Compton, W.C. Introduction to Positive Psikologi. USA: Malloy Incorporated, 2005.

Herusatoto, B. Simbolisme Jawa. Yogyakarta: Ombak Yogyakarta, 2008. Hidayat, Syarif Imam. "Kemiskinan Dalam Perspektif Masyarakat Desa Tertinggal Yang Religius." Disertasi, Universitas Brawijaya, 2011.

Irhan, Mohammad. "Etos Kerja Dalam Perspektif Islam." Jurnal Substansia 14, no. 1 (April 2012).

Nasikun. Isu Dan Kebijakan Penanggulangan Kemiskinan. Diktat Mata Kuliah. Yogyakarta: Program Magister Administrasi Publik Universitas Gadjah Mada, 2001.

Shihab, Muhammad Quraish. Wawasan Alqur'an: Tafsir Maudhu'i Atas Berbagai Persoalan Umat. 14th ed. Bandung: Mizan, 1996.

Sugiyono. Metode Penelitian Kombinasi (Mixed Methods). Bandung: CV. Alfabeta, 2011.

Warsah, Idi, Yusron Masduki, Imron, Mirzon Daheri, and Ruly Morganna. "Muslim Minority In Yogyakarta: Between Social Relationship and Religious Motivation." Qudus International Journal of $\begin{array}{lllll}\text { Islamic Studies } & 7, & & \text { (2019). }\end{array}$ https://doi.org/10.21043/ qijis.v7i2.6873. 